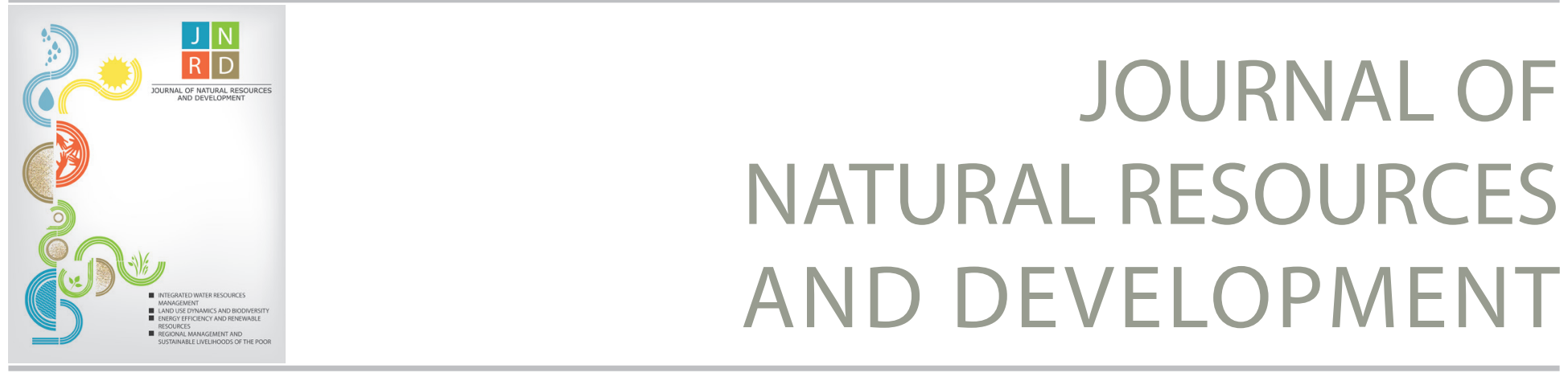

Case study

\title{
Socio-Economic Factors of Small Hydropower and Biogas Plants and their Implications for Rural Energy Poverty Alleviation in Kirinyaga, Kenya
}

\author{
Christine. W. Njiru a*, Sammy C. Letema ${ }^{b}$ and Simon. M. Maingi ${ }^{c}$ \\ a Kagumo Teachers' Training College, P.O. Box 18-10100, Nyeri, Kenya \\ b Environmental Planning and Management Department, Kenyatta University, P.O. Box 43844-00100, Nairobi, Kenya \\ c Environmental Science Department, Kenyatta University, P.O. Box 43844-00100, Nairobi, Kenya
}

* Corresponding author: christine.njiru26.cn@gmail.com

\section{Article history}

Received 09/04/2018

Accepted 14/08/2018

Published 01/10/2018

\section{Keywords}

Adoption

Renewable energy

Modern fuels

Traditional fuels

Energy stacking

\section{Abstract}

Energy is essential for sustainable development and for improving the socio-economic welfare of a community. Sub-Saharan Africa suffers from severe rural energy poverty and minimal access to modern energy services. Adoption of renewable energy technologies is often viewed as a way to alleviate rural energy poverty, but uptake is slow. Socio-economic factors, mainly household income, electricity access, fuels used for cooking, and land tenure, influence adoption of renewable energy technologies. This paper assesses the contribution of small hydropower and biogas technologies in alleviating rural energy poverty in Kirinyaga County, Kenya, where the majority of the population relies on traditional sources of energy. A case study research design was used, with a sample size of 178. Data was collected using a questionnaire survey, the review of project documents, and interviews. Five indicators were used to assess energy poverty. The results indicate medium to low energy poverty and energy stacking; with reliance on traditional sources of energy. Socio-economic factors influence adoption of SHP and biogas. Therefore, adoption of renewable energy technologies does not alleviate rural energy poverty because SHP and biogas are used to supplement rather than replace the use of traditional fuels.

(c) 2018 This is an open access article under the CC BY-NC-ND license (http://creativecommons.org/licenses/bync-nd/4.0/). 


\section{Introduction}

Energy is essential in socio-economic development of any nation as it alleviates poverty, improves welfare, and raises people's living standards [1]. Over the years, there has been an increase in the adoption of renewable energy. In the 1970s, it was promoted to reduce the use of fossil fuels, in the $80 \mathrm{~s}$ and $90 \mathrm{~s}$ to reduce the negative environmental impacts of fossil fuel use, and currently to mitigate climate change [2].

Geographical and historical differences significantly contribute to the presence and characteristics of energy poverty [3]. Energy poverty in developing countries is caused by low levels of electrification and other forms of networked energy provision resulting from economic constraints and inefficient institutions [4]. About $83 \%$ of the population in sub-Saharan Africa relies on traditional fuels, with 74 $\%$ lacking electricity [5]. The majority of the world's poor live in rural areas with limited access to modern energy services [6]. The cost of energy causes a heavy economic burden to low-income households in developing countries like Kenya; where low-income households spend more than $20 \%$ of household income on energy uses [7].

Renewable energy technologies are the fastest growing energy sources in the world and projections indicate they will become major contributors to the energy mixes of many countries [8]. They are essential for sustainable development because they maintain natural capital, improve access to energy, reduce greenhouse gas emissions, reduce environmental and health impacts, and create local socioeconomic development opportunities [9]-[11]. Small hydropower (SHP) is a renewable energy source with enormous potential and can be used as a standalone power source or in hybrid systems with other energy sources. There is no globally agreed definition of SHP, but most countries term plants of up to $10 \mathrm{MW}$ as SHP [12]. Adoption of SHP in Kirinyaga started during the colonial era and has continued to the present. Adoption is attributed to low access to electricity, technological push, development of feed-in tariffs, and promotion of green energy in the country's energy mix. Kirinyaga has 26 SHP projects initiated by communities and companies; with 12 being incomplete, 2 under construction, 9 stalled, and 2 operational. The total installed capacity is $249.3 \mathrm{~kW}$. The operational SHP plants have installed capacities of $11 \mathrm{~kW}$ (Kiangima-Kiangibuini) and $110 \mathrm{~kW}$ (Ndiara). The cost of power from the SHP plants is 2 US\$ per month. The low adoption rate is attributed to lack of technical knowhow, financial constraints, connection to the national grid, and lack of maintenance. Electricity demand is $167 \mathrm{kWh}$ which is the electricity consumption per capita for Kenyan households [13].

Biogas is a renewable energy source that is widely used for cooking, lighting, heating or electricity production. Biogas improves user's health and sanitation, reduces demand for alternative energy sources, is sustainable, creates jobs, produces fertilizer from a digester, offers education opportunities, spurs entrepreneurial activities, and helps in treating and reusing some waste [14]-[15]. Despite the many benefits, biogas technology has not been very successful in developing countries, mainly due to the challenges of operation and maintenance [14]. Data on the number of households with biogas in
Kirinyaga is scant because there is no database, except for the 190 under the Kenya National Domestic Biogas Program. Assessment of energy production from the biogas plants is beyond the scope of this study. Biogas has been promoted by some non-governmental organizations in partnership with national government through subsidized biogas construction in some households and schools from 2008 to 2013. The biogas plants range in size from $4 \mathrm{~m}^{2}$ to $12 \mathrm{~m}^{2}$. Households and schools mostly adopt biogas technology when a subsidy is available. Adoption of biogas is hampered by high initial investment costs e.g. the cost of a family size floating drum plant in most African countries averages 1667 US\$, whereas in Kenya, the fixed capital investment costs are 1535 US\$ $\left(8 \mathrm{~m}^{3}\right)$; 2198 US $\$\left(16 \mathrm{~m}^{3}\right)$; 12176 US\$ $\left(54 \mathrm{~m}^{3}\right)$ and 26,090 US\$ $\left(124 \mathrm{~m}^{3}\right)$; which is not affordable to many households that live on less than US\$2/day [16]. The cost of fuel wood in Kirinyaga ranges from 3.8-12 US\$ per month while the cost of kerosene is about 3 US\$ [17]. These fuels are thus more affordable to low income earners. The SHP and biogas plants have been studied in Kenya, specifically regarding adoption, technology, and challenges. Kathamba $(1.2 \mathrm{~kW})$ and Thima $(2.2 \mathrm{~kW})$ have been documented as the first pilot SHP plants in Kirinyaga [18]-[20]. Later, the United Nations Industrial Development Organization [21] started Kibae SHP and this led to a mushrooming of other projects. The Kenya Tea Development Authority is constructing Nyamindi SHP (1.8MW) [22] and the National Irrigation Board has constructed two plants with a capacity of $20 \mathrm{~kW}$ along irrigation canals [23]. Biogas is recommended to solve environmental and energy problems in Africa [24], though it has been found that socio-economic factors affect adoption of biogas technology in Nakuru [25]. Furthermore, inadequate documentation of biogas production in Kenya makes the sustainability assessment of the biogas plants challenging [26]. SHP development has contributed to electrification in Kenya but is still under-utilized [27]. However, little is known regarding the contribution of SHP and biogas to rural energy poverty alleviation; which this paper addresses.

\section{Methods}

An exploratory case study design was used because it allows use of multiple methods of data collection. The energy poverty assessment was multi-dimensional, derived by partly adopting the method for calculating multi-dimensional energy poverty index [28]-[30]. Table 1 outlines the indicators used in assessing energy poverty and their cut off points derived from a literature review. A household is energy deprived if they do not use electricity for lighting; the main cooking fuel is not electricity, cooking gas or kerosene; they spend more than $10 \%$ of their income on energy expenditure; and there is evidence of indoor pollution due to the cookstove being an open fire, or they use any other fuel besides electricity or gas.

A household is also deprived if the individuals do not own the land they occupy since land availability determines whether they have access to fuel wood locally or if they have to purchase it. This paper assumes that households relying on firewood use open fires and consequently experience indoor pollution. 
Table 1: Energy poverty assessment indicators applied for Kirinyaga case studies

\begin{tabular}{llllc}
\multicolumn{1}{c}{ Dimension } & \multicolumn{1}{c}{ Indicator } & \multicolumn{1}{c}{ Variable } & \multicolumn{1}{c}{ Deprivation- cut-off } & \multicolumn{1}{c}{ (energy poor if) } \\
\hline Cooking & Modern cooking fuel & Traditional cooking fuels (firewood) & Use of traditional sources of energy for cooking & [28], [30], [31] \\
Indoor pollution & Indoor air pollution & Traditional cooking fuels (firewood) & Use of traditional sources of energy for cooking & [28]-[31] \\
Lighting & Electricity access ${ }^{2}$ & Type of energy used for lighting & No use of electricity for lighting \\
Land ownership & Land ownership & Does not own land & Do not own land \\
Household income & Total household income & $>10 \%$ spent on energy & Household spends $>10 \%$ of income on energy \\
\hline
\end{tabular}

In the case studies, respondents use kerosene for lighting in addition to electricity a .

Little is documented regarding renewable energy technologies in Kirinyaga, and there is no database of biogas plant owners; hence purposive sampling was used to fill this gap. Data was collected between July 2015 and February 2016 using questionnaires, project document review, interviews, and direct observation. Two operational community SHP plants, Kiangima-Kiangibuini and Ndiara, which serve 25 and 10 households, respectively, were assessed. The KiangimaKiangibuini case study sample size is 22 users ( 3 were unavailable) and 25 non-users. The non-users are immediate neighbors who rely on electricity from the national grid. The Ndiara case study has 10 members connected to small hydropower, but no comparison is done because the area is yet to be connected to the national grid due to lack of transformers.

Data on biogas adoptees was obtained from the Kenya National Federation of Agricultural Producers and Sub-County Livestock Officers. The sampling frame was 190 biogas users; out of which 60 users and 61 non-users were purposely selected. Respondents for the questionnaire survey of biogas users were randomly sampled within the four Sub-Counties of Kirinyaga; Kirinyaga West (19), East (18), South (6), and Central (17).

Chi square test was used to determine the association between biogas and SHP and energy poverty status. Chi square $\left(\chi^{2}\right)$ was used to assess the relationship between two categorical variables. The independent variables are household income, types of fuels used, and land tenure that determines substitution of energy sources; whereas the dependent variable is the adoption of SHP and biogas technologies.

\section{Results and Discussion}

\subsection{Socio-Economic Characteristics}

In Kiangima-Kiangibuini, there is no significant relationship between level of income and adoption of SHP since there is no major difference in the level of total household income between users and non-users for income below Ksh 10,000. More SHP non-users (65\%) had income between Ksh 10,000 and 40,000 compared to users (55\%) (Table 2). Level of income, therefore, may not influence the adoption of SHP because non-users have more income, yet they have not adopted the technology. There is no statistically significant difference in land tenure between SHP users and non-users. However, land tenure can affect the socio-economic status of the individual because it determines the type of economic activities practiced, and hence total household income.

The majority of households (78 \%) in the Ndiara case study had income between Ksh 10,000 and 50,000, with $22 \%$ earning more than Ksh 50,000 monthly. Households in Ndiara own their land, with $90 \%$ having title deeds. Land tenure does not affect adoption of small hydropower because the SHP plant is not located on an individual's land, but near the river. There is a significant difference in income and land tenure between biogas users and non-users (Table 2). Generally, the majority of the population have a monthly income ranging from Ksh 10,000 - 40,000. However, there are more biogas non-users with an income below Ksh 10,000 (30 \%) compared to users (9\%).

$1 \mathrm{US} \$=100 \mathrm{Ksh}$

Among biogas users, $18 \%$ have an income above Ksh 50,000 while $5 \%$ of non-users earn that amount. The level of household income greatly determines adoption of biogas technology. Most biogas users (91\%) had title deeds for their land compared to non-users (66\%). Land tenure determines adoption of biogas technology because it is a long-term investment needing high initial capital. The farmer must be sure that there will be no land ownership dispute before they can construct the biogas plant.

\subsection{Types and Uses of Fuels for the Kiangima-Kiangibuini Case Study}

The Kiangima-Kiangibuini case study respondents depend on multiple sources of energy (Table 3). Apart from kerosene and firewood, energy consumption for small hydropower users is higher than for non-users (Table 3). Both SHP users (100\%) and non-users (84\%) are connected to the national grid. This is because SHP was initiated before the region was connected to the national grid. However, even after connecting to the national grid, SHP group members did not abandon the project because the power is cheaper than that from the national grid. The problem with SHP is that it does not supply energy for all electrical needs; therefore, it cannot be used for ironing, cooking or to power rural enterprises because of the low voltage. When SHP machines break down, there is a delay before repair due to the participatory nature of management. Therefore, 
Table 2: Impact of socio-economic characteristics on adoption of SHP and biogas in Kirinyaga

\begin{tabular}{|c|c|c|c|c|c|c|c|c|c|}
\hline \multirow[b]{2}{*}{ Variable } & \multicolumn{2}{|c|}{ Kiangima-Kiangibuini } & \multirow[b]{2}{*}{$x^{2}$} & \multirow[b]{2}{*}{$\begin{array}{c}\text { P } \\
\text { (two-sided) }\end{array}$} & \multirow{2}{*}{$\begin{array}{c}\text { Ndiara } \\
\text { SHP users } \\
\text { (\%) }\end{array}$} & \multicolumn{2}{|l|}{ Biogas } & \multirow[b]{2}{*}{$x^{2}$} & \multirow[b]{2}{*}{$\begin{array}{c}\mathrm{P}^{*} \\
\text { (two sided }\end{array}$} \\
\hline & $\begin{array}{c}\text { SHP user } \\
(\%)\end{array}$ & $\begin{array}{c}\text { SHP non-user } \\
(\%)\end{array}$ & & & & $\begin{array}{c}\text { Biogas user } \\
(\%)\end{array}$ & $\begin{array}{c}\text { Biogas non-user } \\
(\%)\end{array}$ & & \\
\hline Total household income & & & 2.51 & 0.516 & & & & 18.63 & 0.002 \\
\hline$<10,000$ & 32 & 35 & & & - & 9 & 30 & & \\
\hline $10,000-20,000$ & 55 & 43 & & & 22 & 22 & 39 & & \\
\hline $30,000-40,000$ & 55 & 22 & & & 45 & 21 & 11 & & \\
\hline $40,000-50,000$ & 9 & 0 & & & 11 & 21 & 9 & & \\
\hline$>50,000$ & & & & & 22 & 9 & 6 & & \\
\hline Land ownership & & & .23 & 1.000 & & & & 3.09 & 0.095 \\
\hline Own land & 95 & 92 & & & 100 & 97 & 88 & & \\
\hline Do not own land & 5 & 8 & & & & 3 & 12 & & \\
\hline Land tenure & & & 1.85 & 0.216 & & & & 11.12 & 0.001 \\
\hline Own land with title deed & 43 & 76 & & & 90 & 91 & 66 & & \\
\hline Own land without title deed & 57 & 24 & & & 10 & 9 & 34 & & \\
\hline
\end{tabular}

* $P$ refers to the probability at which the association between variables is significant. Conventionally the value is significant if $P<0.05$.

there is no major difference between energy sources utilized by SHP users and non-users.

For all types of fuels, there is no significant association between type of fuel and use of SHP (Table 3). Hence, adoption of SHP has not alleviated energy poverty because the users continue to rely on firewood, charcoal, and electricity from the national grid.

Table 3: Association between types of fuels and use of SHP in Kiangima-Kiangibuini, Kirinyaga

\begin{tabular}{|lcccc|}
\multicolumn{1}{c}{ Type of fuel } & $\begin{array}{c}\text { SHP users } \\
(\%)\end{array}$ & $\begin{array}{c}\text { SHP non-users } \\
(\%)\end{array}$ & $\chi^{2}$ & $\begin{array}{c}\text { P } \\
\text { (two sided) }\end{array}$ \\
\hline Firewood & 100 & 100 & $-{ }^{\mathrm{b}}$ & $-{ }^{\mathrm{b}}$ \\
Charcoal & 64 & 56 & 0.283 & 0.767 \\
Kerosene & 14 & 16 & 0.052 & 1.000 \\
National grid electricity & 100 & 84 & 3.847 & 0.112 \\
Liquid petroleum gas & 32 & 24 & 0.357 & 0.745 \\
Biogas & 5 & 0 & 1.161 & 0.468 \\
\hline
\end{tabular}

$\chi^{2}$ could not be computed because use of firewood is a constant. Significant at $\mathrm{P}<0.05 . \mathrm{n}=47^{\mathrm{b}}$

Households can be categorized as facing energy poverty or not based on the amount of money spent on energy (Table 1). There is no statistically significant association between energy poverty status and the use of SHP in a household, $\chi^{2}=4.19 ; \mathrm{df}=1 ; \mathrm{p}=0.109$. Hence, adoption of SHP has not alleviated energy poverty in the KiangimaKiangibuini case study.

\subsection{Types and Uses of Fuels for the Ndiara Case Study}

Ndiara respondents depend on multiple sources of energy: firewood and charcoal for cooking, kerosene for cooking and lighting, small hydropower for lighting, and liquid petroleum gas for cooking; with none adopting biogas. Use of electricity from SHP in Ndiara has not alleviated energy poverty, as all the households still depend on fuelwood for cooking and kerosene for lighting. This was found in a prior study, which analyzed sources of fuel for cooking in Kirinyaga [35].

\subsection{Types and Uses of Fuels for the Biogas Case Study}

Biogas users and non-users depend on multiple sources of energy (Table 4). Both groups depend on both traditional (firewood and charcoal) and modern (kerosene, liquid petroleum gas, electricity, biogas) sources of energy with the exception of biogas for non-users. Both biogas users (54\%) and non-users (82 \%) depend on fuelwood to supplement biogas for cooking and kerosene for cooking and lighting. Both groups always keep kerosene in case of power blackouts. More biogas users depend on the electricity grid (87\%) compared to non-users (65\%) because biogas users depend on electricity to chop animal fodder and to pump water for the animals. A greater number of biogas non-users depend on liquid petroleum gas (37\%) compared to users (20\%) because they supplement fuelwood with liquid petroleum gas for cooking; whereas biogas

Table 4: Association between types of fuels and use of biogas in Kirinyaga

\begin{tabular}{|lcccc|}
\multicolumn{1}{c}{ Type of fuel } & $\begin{array}{c}\text { Biogas users } \\
(\%)\end{array}$ & $\begin{array}{c}\text { Biogas non-users } \\
(\%)\end{array}$ & $\chi^{2}$ & $\begin{array}{c}\text { P } \\
\text { (two sided) }\end{array}$ \\
\hline Firewood & 54 & 82 & 10.53 & 0.002 \\
Charcoal & 20 & 33 & 2.90 & 0.102 \\
Kerosene & 12 & 35 & 9.41 & 0.003 \\
Electricity & 87 & 65 & 7.95 & 0.006 \\
Liquid petroleum gas & 20 & 37 & 4.32 & 0.044 \\
Biogas & 100 & 0 & 1.21 & 0.001 \\
\hline
\end{tabular}

Significant at $\mathrm{P}<0.05 ; \mathrm{n}=121^{\mathrm{c}}$ 
users use liquid petroleum gas to supplement biogas when the digester is not supplying enough biogas. Biogas users depend on it for cooking, with a few using it to power a chaff cutter and for lighting.

There is a significant association between the adoption of biogas and energy poverty, $\chi^{2}=20.11$; $d f=1, p=0.001$. Adoption of biogas contributes to energy poverty alleviation as it reduces consumption of other types of fuel. Biogas users also have a higher consumption of electricity relative to non-users.

\subsection{Contribution of small hydropower and biogas plants to energy poverty alleviation in Kirinyaga}

Table 5 shows the percentage distribution of households affected by different aspects of energy poverty. In the Kiangima-Kiangibuini case study, all SHP users use firewood, spend $>10 \%$ of household income on energy expenditure, and have electricity access; $14 \%$ use kerosene for lighting, and $5 \%$ do not own the land they inhabit. SHP non-users use firewood for cooking, $84 \%$ spend $>10 \%$ of household income on energy expenditure, $16 \%$ use kerosene for lighting, and $8 \%$ do not own the land they occupy. In the Ndiara case study, households use firewood and kerosene for lighting, own the land they occupy, and $20 \%$ spend more than $10 \%$ of household income on energy expenditure. In the biogas case study, $54 \%$ of biogas users use firewood for cooking and $12 \%$ use kerosene for lighting despite having electricity access, $3 \%$ do not own the land they occupy, and $20 \%$ spend more than $10 \%$ of household income on energy expenditure. Among the biogas non-users, $82 \%$ use firewood for cooking, $35 \%$ use kerosene for lighting, $12 \%$ do not own their land, and $65 \%$ spend $>10 \%$ of their income on energy uses. Therefore, households in the three case studies experience some form of indoor air pollution.

Based on the mean score obtained per case study and the cut-off points set out in Table 1, SHP users (64\%) and non-users (62\%) in Kiangima-Kiangibuini and the users (64\%) in Ndiara have medium energy poverty. Therefore, use of SHP has not significantly alleviated energy poverty. Biogas users have low energy poverty (26\%), whereas non-users (55 \%) have medium energy poverty (Table 4). Thus, the adoption of biogas has significantly reduced energy poverty. Amongst all the indicators, use of firewood for cooking has the greatest contribution to energy poverty and directly causes indoor air pollution. Cooking is a basic requirement for each household and this inflates the energy budget, thereby exacerbating energy poverty.

The main causes of energy poverty in Kirinyaga are use of firewood for cooking, kerosene for lighting, and high expenditure on energy. Although Kirinyaga residents have adopted modern forms of energy in the form of biogas and SHP, these modern sources of energy have not completely replaced traditional sources of energy. Consequently, households exhibit energy stacking [36] since biogas and electricity from SHP are inadequate for their uses. Energy stacking is observed in many developing countries [37], [38]. It has been observed that as income improves, households adopt new fuel sources to supplement but not to substitute traditional fuels [39]. Some of the biogas users are not aware that biogas can be used for lighting, and even those who are aware, have not installed biogas lamps. Households use firewood for cooking, especially open fire spaces, which contributes to indoor air pollution. Land ownership can prevent adoption of modern energy sources because a person who is not certain of land tenure [32] may not invest in biogas as it requires high initial capital and is a long-term investment in nature [25]. As such, it has been recommended that subsidies should be introduced to increase adoption [40]. Use of many types of energy inflates the energy expenditure in a household. Therefore, SHP and biogas adoption have not alleviated energy poverty in Kirinyaga because households still depend on traditional energy sources.

\section{Conclusions}

Households in Kirinyaga have adopted SHP and biogas technologies hoping to alleviate energy poverty. The aim is to eliminate the use of traditional fuels for cooking, replacing them with modern fuels and kerosene for lighting with electricity. Biogas and SHP plants have

Table 5: Percentage of Households Affected by Different Dimensions of Energy Poverty in Kirinyaga

\begin{tabular}{|c|c|c|c|c|c|c|c|c|c|c|c|}
\hline \multirow[t]{3}{*}{ Dimension } & \multirow[t]{3}{*}{ Indicator } & \multicolumn{4}{|c|}{ Kiangima-Kiangibuini } & \multirow{2}{*}{\multicolumn{2}{|c|}{$\begin{array}{c}\text { Ndiara } \\
\text { SHP users }\end{array}$}} & \multicolumn{4}{|c|}{ Biogas } \\
\hline & & \multicolumn{2}{|c|}{ SHP users } & \multicolumn{2}{|c|}{ SHP non-users } & & & \multicolumn{2}{|c|}{ Biogas users } & \multicolumn{2}{|c|}{ Biogas non-users } \\
\hline & & $\mathbf{n}$ & $\%$ & $\mathbf{n}$ & $\%$ & $\mathbf{n}$ & $\%$ & $\mathbf{n}$ & $\%$ & $\mathbf{n}$ & $\%$ \\
\hline Cooking $^{d}$ & Modern cooking fuel & 22 & 100 & 25 & 100 & 10 & 100 & 33 & 54 & 49 & 82 \\
\hline Indoor pollution & Indoor air pollution & 22 & 100 & 25 & 100 & 10 & 100 & 33 & 54 & 49 & 82 \\
\hline Lighting ${ }^{d}$ & Electricity access & 3 & 14 & 4 & 16 & 10 & 100 & 7 & 12 & 21 & 35 \\
\hline Land ownership & Land ownership & 1 & 5 & 2 & 8 & 0 & 0 & 2 & 3 & 7 & 12 \\
\hline Household income & Total household income & 22 & 100 & 21 & 84 & 2 & 20 & 12 & 20 & 37 & 62 \\
\hline Mean score & & & 64 & & 62 & & 64 & & 26 & & 55 \\
\hline
\end{tabular}

Data used for cooking is for firewood only and that for lighting is for kerosene use only d Assessment criteria: 0-33 \% low energy poverty; $34-67 \%$ medium energy poverty; 68-100\% high energy poverty ${ }^{\mathrm{e}}$ 
partly alleviated energy poverty, but energy stacking still persists. Promotion of renewable energy technologies for rural energy poverty alleviation should be considered in a broader context taking into consideration the multidimensional nature of energy poverty. The socio-economic and technical needs of target populations should be considered if the beneficiaries are to fully embrace and benefit from renewable energy technologies; otherwise it will remain a mirage.

\section{Appendixes}

Appendix 1. Questionnaires for Users and Non-Users of Biogas

\section{Questionnaire for Users and Non-Users of Biogas in Kirinyaga}

Instruction: As part of my PhD research at Kenyatta University I am conducting a survey to assess the adoption and sustainability of small hydropower and biogas plants and their contribution to energy poverty alleviation in Kirinyaga County. This is an academic questionnaire purely for scientific research and there is no "correct" answer to each question. Your responses will be accorded full confidentiality therefore do not write your name. Results of the study will be made available to all stakeholders. Please tick the correct answer where there are options. For open ended questions, use the space provided. Kindly answer all questions.

\section{Section (a) Interviewee Bio Information}

\begin{tabular}{|l|l|l|l|l|}
\hline \multicolumn{1}{|c|}{$\mathrm{HH}$ member } & Gender & Age & Highest level of education & Occupation \\
\hline Self & & & & \\
\hline Spouse & & & & \\
\hline
\end{tabular}

1. Indicate the number of dependents living in the household..

2. Indicate the total household income (Ksh.) per month.
$<10000[$
$10000-20000[$ ]
20000- 30000 [ ]
$30000-40000[$ ]
40000- $50000[$ ]
$>50000[]$

\section{Section (b) Energy Poverty Assessment}

Please indicate your energy source(s), state how you use them and the cost of each per month.

\begin{tabular}{|l|l|l|l|}
\hline \multicolumn{1}{|c|}{ Source } & Tick where applicable & \multicolumn{1}{c|}{ How it is used } & \\
\hline Firewood & & & \\
\hline Charcoal & & & \\
\hline Kerosene & & & \\
\hline Electricity & & & \\
\hline LPG & & & \\
\hline Biogas
\end{tabular}

Housing quality (Provide information for your main house)

\begin{tabular}{|l|l|}
\hline Roof type & \multicolumn{1}{|c|}{ Tick where applicable } \\
\hline Iron & \\
\hline Tiles & \\
\hline Plastic & \\
\hline Floor type & \\
\hline Concrete & \\
\hline Tiles & \\
\hline Earth & \\
\hline Wall type & \\
\hline
\end{tabular}


(Continued..): Housing quality (Provide information for your main house)

\begin{tabular}{|l|l|}
\hline & \\
\hline Earth & \\
\hline Timber & \\
\hline Iron sheet & \\
\hline Stone & \\
\hline Bricks & \\
\hline Concrete & \\
\hline Timber and stones & \\
\hline Water availability & \\
\hline Piped water inside house & \\
\hline Piped water outside house & \\
\hline No piped water near house & \\
\hline
\end{tabular}

1. How many rooms do you have in your main house?

2. What type of toilet do you mainly use? (Tick one)

Pit latrine [ ] $\quad$ Flush toilet [ ] $\quad$ Pit and flush [ ]

3. Do you own the land? Yes [ ] No [ ].

If yes what is the size?

4. Do you have title deed for the land? Yes [ ] No [ ].

Indicate how you use water in your household and the cost of the water sources applicable to you

\begin{tabular}{|l|l|l|l|}
\hline \multicolumn{1}{|c|}{ Water sources } & \multicolumn{1}{|c|}{ Tick Uses } & \multicolumn{1}{c|}{ Cost/month } \\
\hline Tap water & & & \\
\hline Public stand Pipe & & & \\
\hline River & & & \\
\hline Well & & & \\
\hline Rain water harvesting & & \\
\hline
\end{tabular}

Type of Livestock Kept

\begin{tabular}{|l|l|l|}
\hline \multicolumn{1}{|c|}{ Animal kept } & Number of animals & Animal waste use e.g. selling, manure etc. \\
\hline Cows & & \\
\hline Chicken & & \\
\hline Pigs & & \\
\hline
\end{tabular}

\section{Section (c) Biogas Digester Information (For biogas users only)}

\section{Type of biogas Digester}

\begin{tabular}{|l|l|}
\hline \multicolumn{1}{|c|}{ Type of biogas digester } & \multicolumn{1}{c|}{ Tick where applicable } \\
\hline Fixed dome & \\
\hline Floating drum & \\
\hline Plastic tube & \\
\hline PVC type & \\
\hline
\end{tabular}

5. Explain why you chose the type of biogas digester you are using. 
Size of biogas digester

\section{Size (M3)}

Cost of construction (Ksh)

Age of digester

Operation \& maintenance cost /year

6. Is the size of your biogas unit appropriate for your energy needs? (Tick one) Yes [ ] No [ ].

If no explain why you selected that size...

\section{Construction materials}

\begin{tabular}{|l|l|}
\hline \multicolumn{1}{|c|}{ Type of material } & \multicolumn{1}{c|}{ Tick where applicable } \\
\hline Poly Vinyl Chloride & \\
\hline Bricks and concrete & \\
\hline Plastic bag & \\
\hline Steel drum & \\
\hline
\end{tabular}

7. Why did you choose those types of construction materials?

8. Why have you not installed biogas in your home? (For non-users of biogas only).

\begin{tabular}{|l|l|}
\hline \multicolumn{1}{|c|}{ Reason for not having biogas unit } & Tick where applicable \\
\hline It is expensive & \\
\hline Lack of sufficient water & \\
\hline No contactor available & \\
\hline Not enough cows & \\
\hline Difficult to maintain & \\
\hline Lack of knowledge & \\
\hline Other & \\
\hline
\end{tabular}

Please give any other details:

9. If you are provided with funding would you construct a biogas plant? Yes [ ] No [ ]

10. What are the advantages of using biogas?......

\section{Section (d) Sustainability Assessment}

Please indicate if you agree or disagree with each of the following statements by ticking appropriately.

\begin{tabular}{|c|c|c|c|c|c|c|c|}
\hline Criteria for Assessment & $\begin{array}{l}\text { Strongly } \\
\text { disagree }\end{array}$ & Disagree & $\begin{array}{l}\text { Slightly } \\
\text { disagree }\end{array}$ & $\begin{array}{l}\text { Neither } \\
\text { agree or } \\
\text { disagree }\end{array}$ & $\begin{array}{l}\text { Slightly } \\
\text { agree }\end{array}$ & Agree & $\begin{array}{c}\text { Strongly } \\
\text { agree }\end{array}$ \\
\hline \multicolumn{8}{|l|}{ 11. Spare parts are easily available. } \\
\hline \multicolumn{8}{|l|}{ 12. An operations manual for biogas is needed. } \\
\hline \multicolumn{8}{|l|}{ 13. The biogas plant operates reliably. } \\
\hline \multicolumn{8}{|l|}{ 14. Initial investment cost is high. } \\
\hline \multicolumn{8}{|l|}{ 15. Operation and maintenance cost is high. } \\
\hline \multicolumn{8}{|l|}{ 16. Use of biogas reduces a household's energy costs. } \\
\hline \multicolumn{8}{|l|}{ 17. Local skilled labor for servicing the biogas plants is easily available. } \\
\hline \multicolumn{8}{|l|}{ 18. Use of biogas energy is accepted by the community members. } \\
\hline \multicolumn{8}{|l|}{ 19. The biogas users have adequate management skills. } \\
\hline \multicolumn{8}{|l|}{ 20. The biogas users have safety measures in place. } \\
\hline \multicolumn{8}{|l|}{ 21. The biogas users receive support from relevant institutions e.g. Ministry of Energy. } \\
\hline \multicolumn{8}{|l|}{ 22. The biogas plants provide direct employment to community members. } \\
\hline \multicolumn{8}{|l|}{$\begin{array}{l}\text { 23. The biogas users receive scientific support or additional training from relevant } \\
\text { institutions. }\end{array}$} \\
\hline 24. Connecting to the biogas plant improves a household's standard of living. & & & & & & & \\
\hline
\end{tabular}




\section{(Continued..)}

\begin{tabular}{|c|c|c|c|c|c|c|c|}
\hline Criteria for Assessment & $\begin{array}{l}\text { Strongly } \\
\text { disagree }\end{array}$ & Disagree & $\begin{array}{c}\text { Slightly } \\
\text { disagree }\end{array}$ & $\begin{array}{l}\text { Neither } \\
\text { agree or } \\
\text { disagree }\end{array}$ & $\begin{array}{l}\text { Slightly } \\
\text { agree }\end{array}$ & Agree & $\begin{array}{l}\text { Strongly } \\
\text { agree }\end{array}$ \\
\hline \multicolumn{8}{|l|}{ 25. Use of biogas energy enhances conservation. } \\
\hline \multicolumn{8}{|l|}{ 26. Construction of biogas plants does not negatively affect the environment. } \\
\hline \multicolumn{8}{|l|}{ 27. Use of biogas does not release harmful pollutant emissions to the environment. } \\
\hline \multicolumn{8}{|l|}{ 28. Use of biogas promotes recycling of materials. } \\
\hline \multicolumn{8}{|l|}{ 29. Use of biogas energy does not require any training or awareness. } \\
\hline \multicolumn{8}{|l|}{ 30. There is minimal need for institutional support for biogas technology. } \\
\hline \multicolumn{8}{|l|}{ 31. It is easy to upgrade existing infrastructure for biogas. } \\
\hline \multicolumn{8}{|l|}{ 32. There is no need for financial support to construct biogas plants. } \\
\hline \multicolumn{8}{|l|}{ 33. It is easy to access the biogas plant through the road network. } \\
\hline 34. Biogas plants have low construction and operation costs for every person. & & & & & & & \\
\hline
\end{tabular}

Thank you for your cooperation.

\section{Appendix 2. Questionnaires for SHP Users and Non-Users}

\section{Questionnaire for Users and Non-Users of SHP Plants in Kirinyaga}

Instruction: As part of my PhD research at Kenyatta University I am conducting a survey to assess the adoption and sustainability of small hydropower and biogas plants and their contribution to energy poverty alleviation in Kirinyaga County. This is an academic questionnaire purely for scientific research and there is no "correct" answer to each question. Your responses will be accorded full confidentiality therefore do not write your name. Results of the study will be made available to all stakeholders. Please tick the correct answer where there are options. For open ended questions, use the spaces provided. Kindly answer all questions.

\section{Section (a) Interviewee Bio Information}

\begin{tabular}{|l|l|l|l|l|l|}
\hline \multicolumn{1}{|c|}{$\mathrm{HH}$ member } & Gender & Age & Highest level of education & Occupation & Sources of income \\
\hline Self & & & & & \\
\hline Spouse & & & & \\
\hline
\end{tabular}

1. Indicate the number of dependents living in the household.

2. Indicate the total household income (Ksh.) per month.
$<10000[$ ]
$10000-20000[$ ]
$20000-30000[$ ]
$30000-40000[$ ]
$40000-50000[$ ]
$>50000[$ ]

\section{Section (b) Energy Poverty assessment}

Please indicate your energy source(s), state how you use them and the cost of each per month.

\begin{tabular}{|l|l|l|l|}
\hline \multicolumn{1}{|c|}{ Source } & Tick where applicable & How it is used & \multicolumn{1}{c|}{ Cost/month } \\
\hline Firewood & & & \\
\hline Charcoal & & & \\
\hline Kerosene & & & \\
\hline Electricity & & & \\
\hline LPG & & & \\
\hline Biogas & & \\
\hline
\end{tabular}


Housing quality (Provide information for your main house).

\begin{tabular}{|c|c|}
\hline Roof type & Tick where applicable \\
\hline \multicolumn{2}{|l|}{ Iron } \\
\hline \multicolumn{2}{|l|}{ Tiles } \\
\hline \multicolumn{2}{|l|}{ Plastic } \\
\hline \multicolumn{2}{|l|}{ Floor type } \\
\hline \multicolumn{2}{|l|}{ Concrete } \\
\hline \multicolumn{2}{|l|}{ Tiles } \\
\hline \multicolumn{2}{|l|}{ Earth } \\
\hline \multicolumn{2}{|l|}{ Wall type } \\
\hline \multicolumn{2}{|l|}{ Earth } \\
\hline \multicolumn{2}{|l|}{ Timber } \\
\hline \multicolumn{2}{|l|}{ Iron sheet } \\
\hline \multicolumn{2}{|l|}{ Stone } \\
\hline \multicolumn{2}{|l|}{ Bricks } \\
\hline \multicolumn{2}{|l|}{ Concrete } \\
\hline \multicolumn{2}{|l|}{ Timber and stones } \\
\hline \multicolumn{2}{|l|}{ Water availability } \\
\hline \multicolumn{2}{|l|}{ Piped water inside house } \\
\hline \multicolumn{2}{|l|}{ Piped water outside house } \\
\hline No piped water near house & \\
\hline
\end{tabular}

3. How many rooms do you have in your main house?..

4. What type of toilet do you mainly use?

(Tick one) Pit latrine [ ] Flush toilet [ ] Pit and flush [ ]

5. Do you own the land? Yes [ ] No [ ].

If yes what is the size?

6. Do you have title deed for the land? Yes [ ] No [ ].

Indicate how you use water in your household and the cost of the water sources applicable to you.

\begin{tabular}{|l|l|l|l|}
\hline \multicolumn{1}{|c|}{ Water sources } & \multicolumn{1}{c|}{ Tick Uses } & \multicolumn{1}{c|}{ Cost/month } \\
\hline Tap water & & & \\
\hline Public stand Pipe & & & \\
\hline River & & & \\
\hline Well & & & \\
\hline Rain water harvesting & & & \\
\hline
\end{tabular}

Types of Livestock Kept

\begin{tabular}{|l|l|l|}
\hline \multicolumn{1}{|c|}{ Animal kept } & Number of animals & Animal waste use e.g. selling, manure etc. \\
\hline Cows & & \\
\hline Chicken & & \\
\hline Pigs & & \\
\hline
\end{tabular}

\section{Section (c) SHP Plant Information (For small hydropower plant users only)}


7. Who owns the small hydropower plant?

8. Is the size of your small hydropower plant appropriate for your energy needs? Yes [ ] No [ ]

If no explain why you selected that size..

9. On which river is the small hydropower plant located?

10. Who owns the land where the small hydropower plant is located?

11. Is the area where the small hydropower plant is located always accessible? Yes [ ] No [ ]

12. How many people were involved in construction of the small hydropower plant?......

13. Do you have your own transmission lines? Yes [ ] No [ ]. If no, are you connected to the national grid? Yes [ ] No [ ].

14. What permits do you need for the project and how often are they renewed?

\section{Section (d) Electricity Connection}

15. What sources of electricity do you use? KPLC [ ] Small hydropower project [ ] Other [ ] For other please indicate the source

16. How many years have you been connected to an electricity source?..

17. Why did you choose that provider (source)?

18. What was the initial cost of connecting to power?

19. Before connecting to electricity what were your sources of energy?

20. Where did you get money to pay for the initial connection?.

\section{Section (e) Electricity Use}

21. What do you use electricity for?

22. For lighting purposes, how many bulbs are you allowed to have?

A. 2 [ ] B. 3-4 [ ] C. 5-10 [ ] D. Unlimited [ ]

23. Are there interruptions in the electricity supply? Yes [ ] No [ ]

If yes, what are the causes?

\section{Section (f) Payment for Electricity}

24. Do you have a power meter installed? Yes [ ] No [ ]

25. Is the power meter read regularly? Yes [ ] No [ ]

If no, explain.

26. Do you pay for electricity before or after use? A. Prepay [ ] B. Post-pay

27. Is there an option for paying part of the bill? A. Yes [ ] B. No [ ]

28. How do you pay the bill? 


\section{Section (g) Sustainability Assessment}

Please indicate how you agree or disagree with each of the following statements by ticking appropriately.

\begin{tabular}{|c|c|c|c|c|c|c|c|}
\hline Criteria for Assessment & $\begin{array}{l}\text { Strongly } \\
\text { disagree }\end{array}$ & Disagree & $\begin{array}{l}\text { Slightly } \\
\text { disagree }\end{array}$ & $\begin{array}{c}\text { Neither agree } \\
\text { or disagree }\end{array}$ & $\begin{array}{l}\text { Slightly } \\
\text { agree }\end{array}$ & Agree & $\begin{array}{l}\text { Strongly } \\
\text { agree }\end{array}$ \\
\hline \multicolumn{8}{|l|}{ 29. Spare parts are easily available. } \\
\hline \multicolumn{8}{|l|}{ 30. An operations manual is needed for the machine. } \\
\hline \multicolumn{8}{|l|}{ 31. The power house operates reliably. } \\
\hline \multicolumn{8}{|l|}{ 32. Initial investment cost is high. } \\
\hline \multicolumn{8}{|l|}{ 33. Operation and maintenance cost is high. } \\
\hline \multicolumn{8}{|l|}{ 34. Use of SHP reduces a household's energy costs. } \\
\hline \multicolumn{8}{|l|}{ 35. Local skilled labor to service the SHP power house is easily available. } \\
\hline \multicolumn{8}{|l|}{ 36. Use of SHP energy is accepted by the community members. } \\
\hline \multicolumn{8}{|l|}{ 37. The SHP leaders have adequate management skills. } \\
\hline \multicolumn{8}{|l|}{ 38. The power house and houses of users have safety measures in place. } \\
\hline \multicolumn{8}{|l|}{$\begin{array}{l}\text { 39. The SHP users receive support from relevant institutions e.g. Ministry of } \\
\text { Energy. }\end{array}$} \\
\hline \multicolumn{8}{|l|}{ 40. The SHP plant provides direct employment to community members. } \\
\hline \multicolumn{8}{|l|}{$\begin{array}{l}\text { 41. SHP users receive scientific support or additional training from relevant } \\
\text { institutions. }\end{array}$} \\
\hline \multicolumn{8}{|l|}{ 42. Connecting to the SHP plant improves a household's standard of living. } \\
\hline \multicolumn{8}{|l|}{ 43. Use of SHP energy enhances conservation. } \\
\hline \multicolumn{8}{|l|}{ 44. Construction of the SHP plant does not negatively affect the environment. } \\
\hline \multicolumn{8}{|l|}{$\begin{array}{l}\text { 45. Use of SHP does not release harmful pollutant emissions to the environ- } \\
\text { ment. }\end{array}$} \\
\hline \multicolumn{8}{|l|}{ 46. Use of SHP promotes recycling of materials. } \\
\hline \multicolumn{8}{|l|}{ 47. Use of SHP energy does not require any training or awareness. } \\
\hline \multicolumn{8}{|l|}{ 48. There is minimal need for institutional support for SHP technology. } \\
\hline \multicolumn{8}{|l|}{ 50. There is no need for financial support to construct SHP plants. } \\
\hline \multicolumn{8}{|l|}{ 51. It is easy to access the SHP plant through road network. } \\
\hline 52. SHP plants have low construction and operation costs for every person. & & & & & & & \\
\hline
\end{tabular}

Thank you for your cooperation. 


\section{Acknowledgment}

The authors are grateful to the National Commission for Science, Technology and Innovation in Kenya for providing funding for the research.

\section{References}

[1] A. Akpinar, F. Tavşan, M. İ. Kömürcü, M. H. Filiz, and K. Kaygusuz, "The total electricity energy production of the World, European Union and Turkey: Projections and comparison," Energ. Source. Part B, vol. 7, no. 1, pp. 28-44, 2012. https://doi. org/10.1080/15567240802532767

[2] USAID. (2017, Sep 02). Encouraging renewable energy development [Online]. Available: http://regulationbodyofknowledge.org/wp-content/uploads/2013/04/ NARUC Encouraging Renewable Energy.pdf

[3] L. Živčič, T. Tkalec, and S. Robić, "Energy poverty: Practical and structural solutions for south-east Europe," Sociology and Anthropology, vol. 4, no. 9, pp. 789-805, Sep. 2016. Doi: https://doi.org/10.13189/sa.2016.040902

[4] S. Bouzarovski and S. Petrova, "A global perspective on domestic energy deprivation: Overcoming the energy poverty-fuel poverty binary," Energy Res. Soc. Sci. vol. 10, pp. 31-40, Nov. 2015. Doi: https://doi.org/10.1016/j.erss.2015.06.007

[5] UNECA. (2014, May 31). A green economy in the context of sustainable development and poverty eradication: What are the Implications for Africa? [Online]. Available: http://www1.uneca.org/Portals/rio20/documents/cfssd7/1AfricaGEBackgroundReportEN.pdf

[6] GNESD. (2014, Jun 12). Bioenergy: The potential for rural development and poverty alleviation [Online]. Available: http://orbit.dtu.dk/files/7590946/Bioenergy.pdf

[7] GNESD. (2014, May 31). GNESD policy brief: Achieving energy security in developing countries [Online]. Available: http://www.iee.usp.br/gbio/sites/default/ files $/ 2010 \% 20$ Achieving\%20Energy\%20Security $\% 20$ in\%20Developing $\% 20$ Countries.pdf

[8] M. Rezaei, "The role of renewable energies in sustainable development: Case study Iran," Iran. J. Energy Environ. vol. 4, no. 4, pp. 320-329. Dec. 2013. Doi: https://doi. org/10.5829/idosi.ijee.2013.04.04.02

[9] J. R. P. Manso and N. B. Behmiri "Renewable energy and sustainable development," Estudios de Economica Aplicada, vol. 31, no. 1, pp. 7-34, 2013. Available: http:// www.redalyc.org/articulo.oa?id $=30126353001$

[10] A. M. Omer, "Renewable energy technologies and sustainable development," African Journal of Engineering Research, vol. 1, no. 4, pp.102-116, Oct. 2013. Available: http://www.netjournals.org/pdf/AJER/2013/4/13-041.pdf

[11] P. A. Owusu and S. Asumadu-Sardokie, "A review of renewable energy sources, sustainability issues and climate change mitigation," Cogent Eng., vol. 3, no. 1, 2016. Doi: https://doi.org/10.1080/23311916.2016.1167990

[12] D. Adu, J. Zhang, Y. Fang, L. Suoming and R.O. Darko, "A case study of status and potential of small hydro-power plants in southern African development community," Energy Proced. vol. 141, pp. 352-359, 2017. Doi: https://doi. org/10.1016/j.egypro.2017.11.042

[13] World Bank. (2018, Mar. 14). "Electricity consumption (kWh per capita)" [Online]. Available: https://data.worldbank.org/

[14] T. Bond and M. R. Templeton. "History and future of domestic biogas plants in the developing world." Energy Sustain. Dev., vol. 15, no. 4, pp. 347-354. Dec. 2011, Doi: https://doi.org/10.1016/j.esd.2011.09.003

[15] D. Raha, P. Mahanta and M. Clarke. "The implementation of decentralized biogas plants in Assam, NE India: The impact and effectiveness of the National Biogas and Manure Management Programme," Energ. Policy, vol. 68, pp. 80-91, May 2014. Doi: https://doi.org/10.1016/j.enpol.2013.12.048

[16] B. Amigun and H. von Blottnitz, "Capacity-cost and location-cost analyses for biogas plants in Africa," Resour. Conserv. Recycl., vol. 55, no. 1, pp. 63-73, Nov. 2010. Doi: https://doi.org/10.1016/j.resconrec.2010.07.004

[17] R. Anker and M. Anker, "Living wage report Kenya with a focus on rural mount Kenya area," The Global Living Wage Coalition, Series 1, Rep. 10, 2017 [Online]. Available: https://www.isealalliance.org/sites/default/files/resource/2017-12/ Kenya Living Wage Benchmark Report.pdf

[18] P. Maher. "Community Pico hydro in Sub-Saharan Africa: Case study 1. Site: Kathamba, Kirinyaga District, Kenya," Micro Hydro Centre, The Nottingham Trent University, Jan. 17, 2002 [Online]. Available: https://energypedia.info/images/6/64/ Kenyacasestudy micro hydro.pdf

[19] P. Maher. "Community Pico hydro in Sub-Saharan Africa/ Case Study Two/ Thima, Kirinyaga District, Kenya," Micro Hydro Centre, The Nottingham Trent University Jul. 02, 2002 [Online]. Available: http://www.energyhimalaya.com/directories/casestudies/CaseStudy Thima(b).pdf

[20] P. Maher, N. P. A. Smith, and A. A. Williams, "Assessment of pico hydro as an option for off-grid electrification in Kenya," Renew. Energ, vol. 28, no. 9, pp. 1357-1369, Jul. 2003. Doi: https://doi.org/10.1016/s0960-1481(02)00216-1

[21] UNIDO. (2015, Jun 24). "Independent thematic review: UNIDO Projects for the promotion of small Hydro power for productive use," United Nations Industrial Development Organization, Vienna 2010 [Online]. Available: https://www.unido. org/sites/default/files/2010-02/e-book small-hydro 0.PDF

[22] E. Ingram. (2015, Jun 10). "Kenya tea agency breaks ground on Lower Nyamindi small hydro project" [Online]. Available: http://www.hydroworld.com/articles/2015/08/ kenya-tea-agency-breaks-ground-on-lower-nyamindi-small-hydro-project.html

[23] UNIDO. (2016, Jan 12). "Promoting innovative green energy solutions in Kenya: ULH-MHP project in Kenya" United Nations Industrial Development Organization (UNIDO) [Online]. Available: https://www.unido.org/sites/default/ files/2015-12/09. LCET ULH-MHP KENYA Brochure 0.pdf

[24] A. M. Mshandete and W. Parawira. "Biogas Tectnology research in selected subSaharan African countries-A review," Afr. J. Biotechnol. vol 8, no. 2, pp. 116-125. Jan. 2009.

[25] J. W. Mwirigi, P. M. Makenzi and W. O. Ochola. "Socio-economic constraints to adoption and sustainability of biogas technology by farmers in Nakuru Districts, Kenya," Energy Sustain. Dev., v, no. vol. 13, no. 2, pp. 106-115, 2009. Doi: https://doi. org/10.1016/j.esd.2009.05.002

[26] C. Nzila, J. Dewulf, H. Spanjers, D. Tuigong, H. Kiriamiti and H. van Langenhove. "Multi criteria sustainability assessment of biogas production in Kenya," Appl. Energ., vol. 93, pp. 496-506, 2012. Doi: https://doi.org/10.1016/j.apenergy.2011.12.020

[27] G. Mbaka and M. W. Mwaniki "Small hydro-power plants in Kenya: A review of status, challenges and future prospects," Journal of Renewable Energy and Environment, vol. 3, no. 4, pp. 20-26, 2016.

[28] P. Nussbaumer, M. Bazilian, V. Modi and K. K. Yumkella. (2016, Oct 25). "Measuring energy poverty: Focusing on what matters." OPHI Working Papers 42, University of Oxford, 2011 [Online]. Available: https://ophi.org.uk/measuring-energy-povertyfocusing-on-what-matters/

[29] S. G. Edoumiekumo, S. S. Tombofa and T.M. Karimo, "Multidimensional energy poverty in the south-south geopolitical zone of Nigeria." Journal of Economics and Sustainable Development, vol. 4, no. 20, pp. 96-103, 2013.

[30] M. Bersisa, "Multidimensional measure of household energy poverty and its determinants in Ethiopia," in Economic Transformation for Poverty Reduction in Africa: A Multidimensional approach, London, Routledge, 2017, ch. 4.

[31] F. Sher, A. Abbas and R. U. Awan, "An investigation of multidimensional energy poverty in Pakistan: A province level analysis." Int. J. Energy Economics and Policy vol. 4, no. 1, 2014. 
[32] A. Maxim, C. Mihai, C. Apostoaie, C. Popescu, C. Istrate, and I. Bostan, "Implications and measurement of energy poverty across the European Union," Sustainability, vol. 8, no. 5, p. 483, 2016. Doi: https://doi.org/10.3390/su8050483

[33] Z. Ishmail and P. Khembo, "Determinants of energy poverty in South Africa," J. energy South. Afr., vol. 26, no. 3, pp. 66-78, 2015.

[34] H. Winkler, A. F. Simões, E. L. la Rovere, M. Alam, A. Rahman, and S. Mwakasonda, "Access and affordability of electricity in developing countries," World Dev., vol. 39, no. 6, pp. 1037-1050, 2011. Doi: https://doi.org/10.1016/j.worlddev.2010.02.021

[35] Kenya National Bureau of Statistics (KNBS) and the Society for International Development (SID). (2015, Jul 17). "Exploring Kenya's inequality: Pulling apart or pooling together: Kirinyaga County," Nairobi [Online]. Available: http://inequalities. sidint.net/kenya/wp-content/uploads/sites/2/2013/09/Kirinyaga.pdf

[36] H. Osiolo, Enhancing household fuel choice and substitution in Kenya, Nairobi, Kenya: Kenya Institute for Public Policy Research and Analysis, 2009.

[37] A. Yonemistu, M. Njenga, M. Liyama and S. Matsushita. "A choice experiment study on the fuel preference of Kibera slum households in Kenya," Wit. Trans. Ecol. Envir., vol. 186, pp. 821-830. 2015. Doi: https://doi.org/10.2495/esus140731

[38] A. Mekonnen and G. Kohlin. (2017, Mar 23). "Determinants of household fuel choice in major cities in Ethiopia," Environment for Development, Discussion Paper Series, 2008 [Online]. Available: http://www.rff.org/files/sharepoint/Worklmages/ Download/EfD-DP-08-18.pdf

[39] B. van der Kroon, R. Brouwer, and P. J. H. van Beukering, "The energy ladder: Theoretical myth or empirical truth? Results from a meta-analysis," Renewable and Sustainable Energy Reviews, vol. 20, pp. 504-513, 2013. Doi: http://dx.doi. org/10.1016/j.rser.2012.11.045

[40] A. Ngigi. (2012, Nov 6). "Kenya National Domestic Biogas Programme. An initiative under the Africa Biogas Partnership Programme," PID for the Kenya National Domestic Biogas Programme, Nov. 2009; Updated Feb. 2010 [Online]. Available: http://www.build-a-biogas-plant.com/PDF/biogas programme implementation kenya.pdf 